\title{
Induced Somatic Aberrations and Chlorophyll Mutations in Capsicum by Insecticides
}

\author{
N. Devadas, A. Sadanandam, R. Kishan Rao and K. Subhash \\ Cytogenetics Laboratory, Botany Department, Kakatiya University, \\ Warangal 506009 , India
}

Accepted November 13, 1985

Production of the chromosomal aberrations and chlorophyll mutations are essential parameters for the index of mutation frequency and for studying the biological effects (Brewen and Preston 1973, Kihlman 1975, Grant 1978, Grower and Tyagi 1979, Singh et al. 1980). Demonstration of mutagenecity of some common pesticides has evoked considerable interest (Epstein and Legator 1971). In recent years most of the pesticides are proved to be mutagenic agents and are causing changes in genetic constitution of organism similar to those produced by radiation. So far effect of pesticides was studied mostly on test plant system and literature on major plants is scanty. Therefore it was thought of interest to find the effects of pesticides on a commercially important vegetable crop plant like chilli.

This communication deals with the somatic chromosomal aberrations and chlorophyll mutants induced by four insecticides viz. DDVP, TARA 909, Phosphomidon and Monocrotophos on Capsicum annuum $\mathrm{L}$.

\section{Materials and methods}

Pure seeds of Capsicum annuum L. cultivar $\mathrm{G}_{3}$ obtained from National Seeds Corporation, Warangal, India. The seeds were soaked in distilled water for $24 \mathrm{hrs}$ and then treated with insecticidal chemicals of each for $24 \mathrm{hr}$. The treated seeds were washed thoroughly for $1 \mathrm{hr}$ in running tap water and sown in experimental plots along with control.

Table 1. Common or trade name of insecticide, active ingredients and source

\begin{tabular}{clll}
\hline $\begin{array}{c}\text { S. } \\
\text { no. }\end{array}$ & \multicolumn{1}{c}{$\begin{array}{c}\text { Trade name of the } \\
\text { insecticide }\end{array}$} & \multicolumn{1}{c}{ Active ingredient } & \multicolumn{1}{c}{ Source } \\
\hline 1. & DDVP $(97 \%)$ & $\begin{array}{l}\text { 2,2-Dichloroethenyl dimethyl } \\
\text { phosphate }\end{array}$ & Hindustan Ciba-geigy Limited \\
2imethyl 1-methy -3-(Methyl- & Monocrotophos $(77.04 \%)$ & Hindustan Ciba-geigy Limited \\
amino)-3-oxo-1-propenyl phosphate & Hindustan Ciba-geigy Limited \\
3. Phosphomidon (94.7\%) & $\begin{array}{l}\text { 2-Chloro-3-(diethylamino)- } \\
\text { 1-methyl-3-oxo-1-propenyl } \\
\text { dimethyl phosphate }\end{array}$ & $\begin{array}{l}\text { 0,0-dimethyl 3-(N-methyl } \\
\text { carbamoylmethyl)phosphoro- } \\
\text { dithioate }\end{array}$ & $\begin{array}{l}\text { Shaw Wallace \& Company } \\
\text { Limited }\end{array}$ \\
4. TARA 909 (30 EC) & (Dimethoate) & & \\
\hline
\end{tabular}

Four insecticides i.e., DDVP, TARA 909, Phosphomidon and Monocrotophos are organophosphorus compounds. The insecticides obtained from various commercial sources are listed in Table 1. Four concentrations, $0.1 \%, 0.3 \%, 0.5 \%$ and $1.0 \%$ of each insecticide were freshly prepared with distilled water and adjusted to a $\mathrm{pH} 7$ at room temperature $27^{\circ} \mathrm{C}$.

In order to study chromosomal behaviour in mitotic system, the root tips were fixed in acetic-alcohol $(1: 3)$ and cytological preparations were made with aceto-orcein. For determi- 
nation of the frequency and spectrum of chlorophyll mutations, the $M_{1}$ plants were harvested separately and sown in $\mathbf{M}_{2}$ generation on plant progeny basis. Frequency, spectrum and segregation of various chlorophyll mutants were scored in $\mathrm{M}_{2}$ generation.

\section{Results}

The effects of the various treatments with four insecticides on somatic chromosomes are given in Table 2. Mitotic index was severely reduced as the concentration increased. Almost all treatments induced a significant amount of cytological damage. Chromosomal aberrations were not detected in control. It was recorded that the frequency of chromosomal alterations was increasingly proportionate to the increase in concentration of chemical. Among the four insecticides DDVP induced drastic aberrations followed by TARA 909, Phosphomidon and Monocrotophos. Concerning the types of induced abnormalities disturbed meta- and

Table 2. Frequency of mitotic anamolies induced by four insecticides in $C$. annuum

L. cultivar $\mathrm{G}_{3}$

\begin{tabular}{|c|c|c|c|c|c|c|c|}
\hline \multirow{2}{*}{$\begin{array}{c}\text { Mutagenic } \\
\text { agent }\end{array}$} & \multirow{2}{*}{ Treatment } & \multirow{2}{*}{$\begin{array}{c}\text { Metaphase } \\
\% \\
\text { Fragments }\end{array}$} & \multicolumn{2}{|c|}{ Anaphase $\%$} & \multicolumn{2}{|c|}{ Telophase $\%$} & \multirow{2}{*}{ Micronuclei \% } \\
\hline & & & Frag. & Brid. & Frag. & Brid. & \\
\hline \multirow[t]{4}{*}{ DDVP } & $0.1 \%$ & 0.62 & 0.46 & - & 0.26 & - & - \\
\hline & $0.3 \%$ & 1.41 & 1.26 & 0.72 & 1.06 & - & - \\
\hline & $0.5 \%$ & 3.22 & 3.12 & 2.06 & 2.76 & 0.74 & 0.86 \\
\hline & $1.0 \%$ & 4.98 & 4.79 & 3.18 & 3.68 & 1.09 & 2.24 \\
\hline \multirow[t]{4}{*}{ TARA 909} & $0.1 \%$ & 0.46 & 0.23 & - & 0.19 & - & - \\
\hline & $0.3 \%$ & 1.36 & 0.96 & 0.18 & 0.84 & - & - \\
\hline & $0.5 \%$ & 3.09 & 2.83 & 1.96 & 2.58 & 0.69 & 0.74 \\
\hline & $1.0 \%$ & 4.82 & 4.62 & 2.69 & 3.02 & 0.98 & 1.87 \\
\hline \multirow[t]{4}{*}{ Phosphomidon } & $0.1 \%$ & 0.32 & - & 一 & - & - & - \\
\hline & $0.3 \%$ & 1.09 & 0.86 & - & 0.72 & - & - \\
\hline & $0.5 \%$ & 2.97 & 2.69 & 1.74 & 2.25 & 0.49 & 0.62 \\
\hline & $1.0 \%$ & 3.56 & 3.05 & 2.08 & 2.86 & 0.74 & 1.54 \\
\hline \multirow[t]{4}{*}{ Monocrotophos } & $0.1 \%$ & - & - & - & - & - & - \\
\hline & $0.3 \%$ & 0.91 & 0.74 & - & 0.65 & - & - \\
\hline & $0.5 \%$ & 2.28 & 2.09 & 1.14 & 1.87 & 0.34 & - \\
\hline & $1.0 \%$ & 3.22 & 2.97 & 1.78 & 2.26 & 0.51 & - \\
\hline
\end{tabular}

anaphases comprised the most dominant type. Considerable percentage of anaphase bridges and lagging chromosomes were noticed. The common chromosomal aberrations at metaphase were unoriented chromosomes (Figs. 1,2) and clumping of chromosomes (Fig. 3) in all treatments. At anaphase, double bridges, single bridge with fragments (Figs. 4, 7,8) and laggards (Fig. 6) were frequently recorded. However, there were increased number of fragments present in a cell than the number of bridges. The fragments were either free or remained attached to the bridges and varied in size and shape (Figs. 5, 6). Most of the fragments were rod shape and some of them occurred in pairs (Figs. 5,6). At telophase chromatid bridges with many fragments and chromosomal bridges with fragments were noticed (Fig. 7). Micronuclei presumably aggregation of fragments or laggards were also recorded (Fig. 9).

A number of chlorophyll mutant seedlings were scored in all treated samples. Spectrum of chlorophyll mutants included xantha, albina, chlorina, alboviridis, xanthoviridis and virescence. The data on chlorophyll mutations were scored on the basis of mutant seedlings in the total population and the data are summerised in Table 3. Chlorophyll mutation frequency 
increases with increasing concentration of chemical. Different types of chlorophyll mutations observed are described below:

1. Xantha: Yellow to yellowish white, lethal (10-15 days), carotenoids present but chlorophylls absent.

2. Albina: White, lethal (6-7 days). No chlorophylls or carotenoids are formed.

3. Chlorina: Yellowish green, lethal (10-12 days, rarely 30 days). However, very few of them which were having light yellowish green survived till maturity and set a few seeds.

4. Xanthoviridis: Green with yellow apex, viable.

5. Albovividis: Green with white apex, viable.

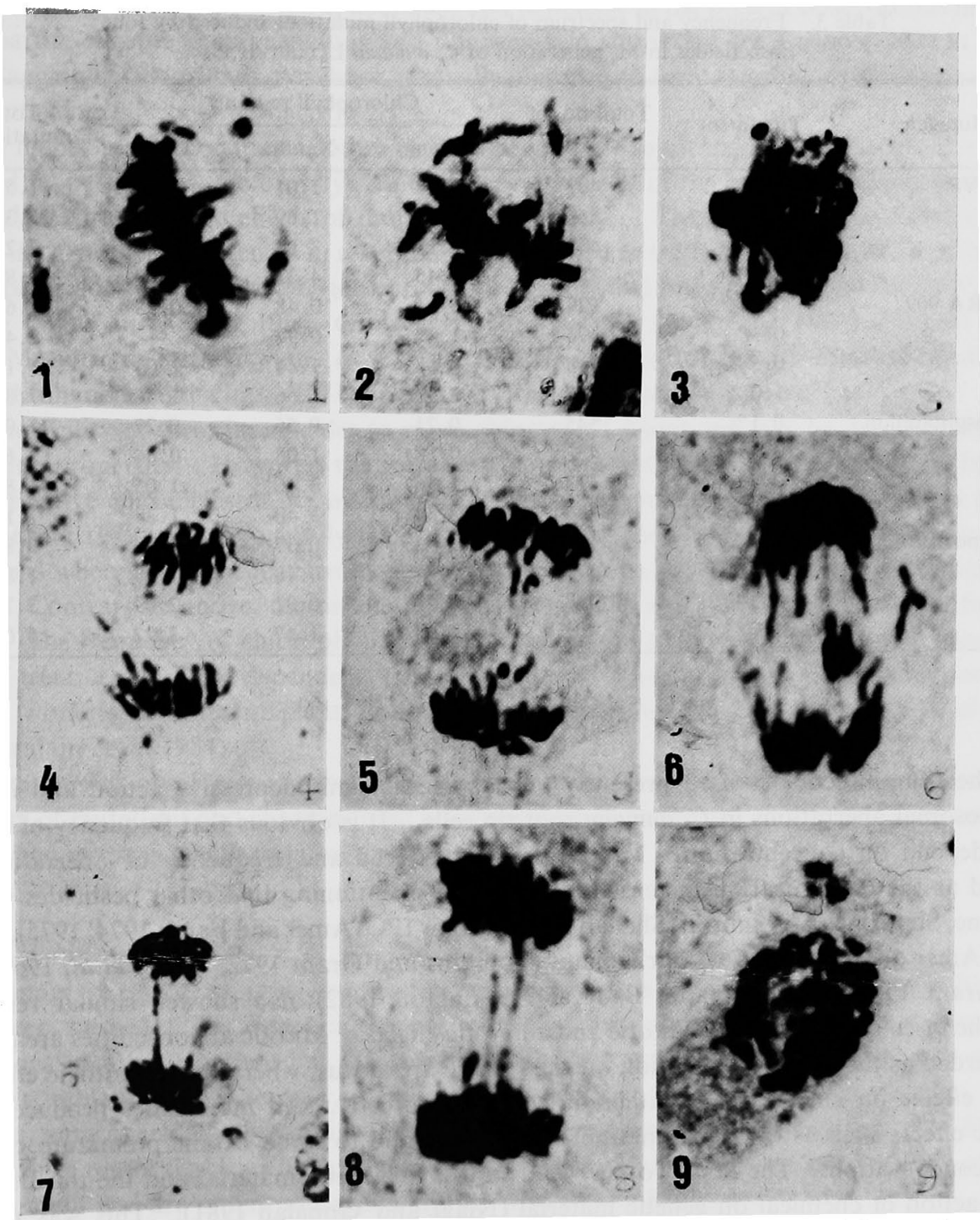

Figs. 1-9. 1, scattered fragments at metaphase. 2, stickiness of chromosome and fragments at metaphase. 3, pronounced stickiness at metaphase. 4, fragments at anaphase. 5, bridge and fragments at anaphase. 6, lagging chromosomes and paired fragments at anaphase. 7, single bridge and fragments at telophase. 8, double bridge, fragments and stickiness of chromosomes at telophase. 9, micronuclei at telophase. 
6. Virescence: Light green, normally change into normal green viable.

It can be seen that xantha nd albina types were most frequent followed by chlorina relative to others found in the $M_{6}$ generation. The present studies revealed that predominantly TARA 909 produced albina and xantha while only xantha found in DDVP and Phosphomidon treatments. Monocrotophos predominantly produced chlorina mutants. Chlorophyll mutations like those of albovividis, xanthoviridis and virescence recorded in $\mathbf{M}_{2}$ generation were excluded from analysis since they were produced in a low frequency. The order of effciency of the insecticides to induce chlorophyll mutations was as follows:

$$
\text { DDVP }>\text { TARA 909 }>\text { Phosphomidon }>\text { Monocrotophos }
$$

Table 3. Frequency and spectrum of chlorophyll mutations induced by four insecticides in $\mathrm{M}_{2}$ generation of $C$. annuum $\mathrm{L}$. cultivar $\mathrm{G}_{3}$

\begin{tabular}{|c|c|c|c|c|c|c|}
\hline \multirow{2}{*}{ Mutagen } & \multirow{2}{*}{ Treatment } & \multirow{2}{*}{$\begin{array}{l}\text { Total no. of } \\
\text { seedlings }\end{array}$} & \multicolumn{3}{|c|}{ Chlorophyll mutants \% } & \multirow{2}{*}{$\begin{array}{c}\text { Total } \\
\text { mutation \% }\end{array}$} \\
\hline & & & Albina & Xantha & Chlorina & \\
\hline \multirow[t]{4}{*}{ DDVP } & $0.1 \%$ & 492 & - & 1.01 & 0.56 & 1.57 \\
\hline & $0.3 \%$ & 469 & 0.67 & 1.69 & 0.98 & 3.34 \\
\hline & $0.5 \%$ & 408 & 2.11 & 3.88 & 1.24 & 7.23 \\
\hline & $1.0 \%$ & 386 & 3.45 & 4.31 & 2.09 & 9.85 \\
\hline \multirow[t]{4}{*}{ TARA 909} & $0.1 \%$ & 529 & 0.91 & 0.48 & 0.28 & 1.67 \\
\hline & $0.3 \%$ & 496 & 1.47 & 0.97 & - & 2.44 \\
\hline & $0.5 \%$ & 468 & 2.68 & 1.44 & 1.03 & 5.15 \\
\hline & $1.0 \%$ & 406 & 3.94 & 2.56 & 1.36 & 7.86 \\
\hline \multirow[t]{4}{*}{ Phosphomidon } & $0.1 \%$ & 545 & 0.21 & 0.56 & 0.27 & 1.04 \\
\hline & $0.3 \%$ & 452 & 0.68 & 1.08 & 0.84 & 2.60 \\
\hline & $0.5 \%$ & 422 & 1.36 & 2.46 & 1.05 & 4.87 \\
\hline & $1.0 \%$ & 396 & 2.34 & 3.40 & 1.38 & 7.12 \\
\hline \multirow[t]{4}{*}{ Monocrotophos } & $0.1 \%$ & 548 & - & 0.37 & 0.49 & 0.86 \\
\hline & $0.3 \%$ & 479 & 0.31 & 0.48 & 1.08 & 1.87 \\
\hline & $0.5 \%$ & 448 & 0.72 & 0.91 & 2.09 & 3.72 \\
\hline & $1.0 \%$ & 402 & 1.13 & 1.67 & 3.22 & 6.02 \\
\hline
\end{tabular}

\section{Discussion}

The four insecticides used presently exert a marked mitodepressive action and induced chromosomal aberrations in $C$. annuum root tip cells. It is obvious that frequency of aberrations depend on concentration. Mitotic activity reduced and frequency of aberrations increased as the concentration increased. It is worth mentioning that other pesticides such as Diamine, Simazine and Linuron (Shehab 1971), Rogor IPC (Amer and Farah 1974, 1975), Leptophos (Amer and Farah 1979), Carbamates (Tomkins and Grant 1972, Tobgy et al. 1969, Wuu and Grant 1966, Badr 1983a, b, Badr and Elkington 1982) also showed similar results.

The insecticides produced mitotic and a mitotic effects. Mitotic abnormalities are generally regarded as the result of an action on the spindle apparatus, whereas chromotoxic effects indicate effects on chromosomes either directly or indirectly. All insecticides produced cytogenetic effects such as bridge formation, micronuclei and to some extant premature chromosome condensation. The first two may lead to loss of genetic material and the third suggests direct action of chemical on genetic material (Njagi and Gopalan 1981). This was reported earlier by Badr (1983a, b). All insecticides induced chromosomal stickiness, breaks and bridges. Stickiness is prominent, it is generally regarded as physiological and unspecific disturbance and has been attributed to an action on the proteins of chromosomes, similar results were observed by El-Sadek (1972) and Tomkins and Grant (1972). The breaks and laggards 
may be due to a major interaction of the insecticides in the cells may be with the proteins of the spindle apparatus and the proteins which form an integral part of the chromosomes (Wolff 1963, Wuu and Grant 1966). Since enzymes are known to play a major role in maintaining the numerous biochemical processes which occur in a cell, the application of pesticide may destroy, inhibit or enhance the synthesis of certain enzymes and so upset the cell system (Wuu and Grant 1966). The stickiness, breaks and bridges were reported with other pesticides (Tobgy et al. 1969, Amer and Farah 1976, Badr 1983a, b and Njagi and Gopalan 1981).

The chromosomal bridges may be attributed to the general stickiness of chromosomes and the subsequent failure of anaphase separation (Abraham and Koshy 1979) or it may be the result of chromosome breakage and reunion (Tomkins and Grant 1972, Grant 1978, Badr 1983a, b). Presence of paired fragments at anaphase and telophase in the present observations indicates monopartite chromosome behaviour and this was also supported by Kalloo (1972) in Pisum. Some lagging chromosomes may have gradually clumped to form micronuclei; micronuclei are true mutagenic effects (Auerbach 1962).

In higher plants no study appears to have been made to estimate the chlorophyll mutants induced by pesticides. Chlorophyll mutations provide one of the most dependable indices for the evaluation of genetic effects of mutagenic treatments. The results of this experiment revealed the genotypic differences in response were observed in the form of frequencies of induced chlorophyll mutations in the $\mathrm{M}_{2}$ generation. The same had been reported earlier in Hordeum vulgare (Wuu and Grant 1966, Grower and Tyagi 1979, Singh et al. 1980). Wheat (Goud 1967), Mungbean (Rathnaswamy et al. 1978, Bahl and Gupta 1982), with Pisum (Lofroth et al. 1969), Mohandas and Grant (1972) reported albina mutant with 2,4-D.

The ability of these insecticides to cause chlorophyll mutations may be due to their DNA alkylating properties. However, the variations in the mutation frequencies may be a function of the relative efficiencies of the insecticides to reach and/or act on the cellular target (Panda and Sharma 1979). It is generally believed that ionizing radiation produced a high frequency of albinas whereas the chemical mutagens produced high frequency of other types (Gustafsson 1963). Contrary to above, the results revealed the xantha and albina were the most frequent types. The frequency of chlorophyll mutations was found to be concomitant with concentration of treatment. Dose dependent increase in the mutation frequency has been reported by several workers in different plant systems (Prasad and Das 1980, Sadanandam et al. 1981, Venkatrajam et al. 1984).

The present observations reveal that the insecticides are potentially capable of producing a variety of mutations and chromosomal aberrations in chilli and are potent mutagens as other established mutagens with radiomimetic action.

\section{Summary}

Mutagenic effects of four insecticides on soaked seeds of Capsicum annuum cultivar $\mathrm{G}_{3}$ have been studied. The insecticides used presently induced various types of chromosomal alterations in meristematic cells. Details of aberrations are described and probable reasons for their induction are discussed. Chlorophyll mutations of six types, viz., xantha, albina, chlorina, xanthoviridis, alboviridis and virescence were recorded in $\mathrm{M}_{2}$ generation. The present findings reveal that four insecticides potentially are capable of producing a variety of mutations in chilli and are potent mutagenic agents with radiomimetic action.

\section{Acknowledgements}

The authors are greatful to Prof. Jafar Nizam for his constant encouragement and to the 
commercial firms for providing the samples of insecticides. The financial assistance to one of us (RKR) by UGC, New Delhi is greatly acknowledged.

\section{References}

Abraham, S. and Koshy, M. P. 1979. Mutagenic potential of green chillies, Cytologia 44: 221-225.

Amer, S. M. and Farah, O. R. 1974. Cytological effects of pesticides VI. Effect of the insectide 'Rogor' on the mitosis of Vicia faba and Gossypium barbadense. Cytologia 39: 507-514.

- and - 1975. Cytological effects of pesticides VII. Mitotic effects of isopropyl-N-pheny! carbamate and 'Duphar'. Cytologia 40: 21-29.

- and - 1976. Cytological effects of pesticides VIII. Effects of the carbamate pesticides 'IPC', 'Rogor' and 'Duphar' on Vicia faba. Cytologia 41: 597-606.

- and - 1979. Cytological effects of pesticides IX. Effects of the phosphorothiote insecticide Leptophos on Vicia faba. Cytologia 44: 907-913.

Auerbach, C. 1962. Mutagenesis, with particular reference to chemical factors. pp. 78-166. In W. J. Schull (ed.) Mutations. Univ. Michigan Press, Ann Arbor.

Badr, A. 1983a. Mitodepressive and chromotoxic activities of two herbicides in Allium cepa. Cytologia 48: $451-457$.

- 1983b. Cytogenetic activities of a triazine herbicide in root tips of Allium cepa and Vicia faba. Mut. Res. 117: $173-182$.

- and Elkington, T. T. 1982. Antimitotic and chromotoxic activities of isoproturon in Allium cepa and Hordeum vulgare. Environ. Exptl. Botany. (in press).

Bahl, J. R. and Gupta, P. K. 1982. Chlorophyll mutations in Mungbean (Vigna radiata (L.) Wilczek). Theor. Appl. Genet. 63: 23-26.

Brewen, J. G. and Preston, R. J. 1973. Chromosome aberrations as a measure of mutagenesis: Comparison in vivo and in vitro and in somatic and germ cells. Environ. Hlth. Persp. 22: 157-166.

El-Sadek, L. M. 1972. Mitotic inhibition and chromosomal aberrations induced by some arylasonic acids and its compounds in root tips of maize. Egypt. J. Genet. Cytol. 1: 218-224.

Epstein, S. S. and Legator, M. 1971. The mutagenecity of pesticides. MIT Press, MA.

Goud, J. V. 1967. Induced mutations in bread wheat. Indian J. Genet. 27: 40-55.

Grant, W. F. 1978. Chromosomal aberrations in plants as a monitoring system. Environ. Hlth Persp. 27: $37-43$.

Grower, I. S. and Tyagi, P. S. 1979. Induction of chlorophyll mutants by some common pesticides. Indian J. Expt1. Biol. 17: 609-611.

Gustafsson, A. 1963. Productive mutations induced in barley by ionizing radiations and chemical mutagens. Hereditas 30: 211-263.

Kalloo 1972. Chromosomal alterations in mitotic and meiotic systems as influenced by gamma rays in Pisum. Cytologia 37: 643-651.

Kihlman, B. A. 1975. Root tips of Vicia faba for the study of the induction of chromosomal aberrations. Mutation Res. 31 : 401-412.

Lofroth, G., Kim, C. and Hussain, S. 1969. Alkylating property of 2,2-dichloro vinyl dimethyl phosphate. A disregarded hazard. EMS Newsl. 2: 21-27.

Mohandas, T. and Grant, W. F. 1972. Cytogenetic effects of 2,4-D and amitrole in relation to nuclear volume and DNA content in some higher plants. Can, J. Genet. Cytol. 14: 773-778.

Njagi, G. D. E. and Gopalan, H. N. B. 1981. Mutagenecity testing of herbicides, fungicides and insecticides I. Chromosome aberrations in Vicia faba. Cytologia 46: 169-172.

Panda, B. B. and Sharma, C. B. S. R. 1979. Organophosphate induced chlorophyll mutations in Hordeum vulgare. Theor. Appl. Genet. 55: 253-255.

Prasad, A. B. and Das, A. K. 1980. Studies of induced chlorophyll mutants in Lathyrus sativus L. Cytologia 45: $335-341$.

Rathnaswamy, R., Krishnaswami, S. and Marappan, P. V. 1978. Radiosensivity studies in green gram (Vigna radiata (L.) Wilczek). Madras Agric. J. 65: 351-356.

Sadanandam, A., Kumaraswamy, G. and Subhash, K. 1981. Hydroxylamine induced chlorophyll mutants in Capsicum. Indian J. Exp. Biol. 19: 395.

Shehab, A. S. 1971. Cytological and growth effects of some herbicides. Ph. D. Dissertation. University College of Girls, Ain Shams University.

Singh, R. M., Singh, A. K., Singh, R. B., Singh, J. and Singh, B. D. 1980 . Chlorophyll mutations induced by 
seed treatment with certain insecticides in barley (Hordeum vulgare). Indian J. Exp. Biol. 18: 13961397.

Tobgy, A. H., Selim, A. R. and Farag, S. 1969. Effects of the herbicides CIPC (isopropyl-N-3-chlorophenyl carbamate) on mitosis in root tips of Allium cepa and Vicia faba. Bull. Fac. Agric. Cairo Univ. 20: 245-257.

Tomkins, D. J. and Grant, W. F. 1972. Comparative cytological effects of the pesticides menazon, metrbromuron and tetrachloro-iso-phthalonitrile in Hordeum and Tradescantia. Can. J. Gent. Cytol. 14: 245-256.

Venkatrajam, M., Sadanandam, A., Devadas, N. and Subhash, K. 1984. Mutagenic effects of Mitomycin-C in Capsicum. Indian Bot. Reptr. 3(1): 56-59.

Wuu, K. D. and Grant, W. F. 1966. Morphological and somatic chromosomal aberrations induced by pesticides in barley (Hordeum vulgare). Can. J. Gent. Cytol. 8: 481-501.

Wolff, S. 1963. Radiation-induced Chromosome Aberrations. Columbia Univ. Press, N. Y. 